\title{
L'émergence du réseau d'assainissement
} pneumatique

Une controverse sanitaire à la fin du XIXe siècle

\section{Thierry Poujol}

\section{OpenEdition \\ Journals}

Édition électronique

URL : https://journals.openedition.org/tc/719

DOI : $10.4000 /$ tc. 719

ISSN : 1952-420X

\section{Éditeur}

Éditions de l'EHESS

Édition imprimée

Date de publication : 1 novembre 1991

ISSN : 0248-6016

\section{Référence électronique}

Thierry Poujol, «L'émergence du réseau d'assainissement pneumatique », Techniques \& Culture [En ligne], 16 | 1991, mis en ligne le 10 janvier 2006, consulté le 29 septembre 2022. URL : http:// journals.openedition.org/tc/719; DOI : https://doi.org/10.4000/tc.719

Ce document a été généré automatiquement le 29 septembre 2022.

Tous droits réservés 
L'émergence du réseau d'assainissement pneumatique

Une controverse sanitaire à la fin du XIXe siècle

Thierry Poujol 